\title{
Scientific approaches to a body in the spiritual-physical market place
}

\author{
Karjalainen, Mira
}

Brill

2012

Karjalainen, M 2012 , Scientific approaches to a body in the spiritual-physical market place . in D Cave \& R S Norris (eds), Religion and the Body : Modern Science and the Construction of Religious Meaning . vol. 2012 , Brill , Boston , pp. 199-216 .

http://hdl.handle.net/10138/340696

unspecified

acceptedVersion

Downloaded from Helda, University of Helsinki institutional repository.

This is an electronic reprint of the original article.

This reprint may differ from the original in pagination and typographic detail.

Please cite the original version. 


\section{Scientific Approaches to Body in the Spiritual-physical Marketplace}

Mira Karjalainen

Everything that we do, we do in our bodies; therefore also spiritual and religious experiences inevitably are bodily experiences. Yet, if spirituality and religiosity are always profoundly embodied practices, how should we view such practices that consciously involve the physical body as a medium of spiritual growth? While research is starting to recognize the need to study spiritual embodiment, little attention has been paid to practices that approach spirituality through body.

This chapter looks at embodied spiritual practices in physical exercises, giving a special attention to those exercises related to religious traditions. There are number of globally popular physical leisure activities that are connected to religions: yoga with Hinduism, and a variety of Asian martial arts - from Chinese taijiquan to Japanese karatewith Buddhism, Confucianism, Daoism, and Shinto. While their approach to religion varies, all these exercises enable their practitioners to experience spirituality through embodiment. These exercises illustrate the complex relations of spirituality, body and the practice of physical exercises in late-modern urban cultures. 'Spirituality' is employed here as a different, but not entirely separate concept from religiosity: religiosity refers to more conventional forms of devotion, mostly within an established religion; spirituality emphasizes the personal unique experiences and practices whose importance and meaning are defined by the individual. ${ }^{1}$ With regard to embodiment, this means that one is aware of one's body and its sensations, and views them as genuine (re)sources for knowledge and experiences.

\footnotetext{
${ }^{1}$ The literature on sociology of religion still fails to establish the relationship between concepts of spirituality and religiosity, as there are five possible relationships between these two concepts, according to Eileen Barker (2008). First, spirituality and religiosity are synonymous and thus interchangeable. Second, spirituality is a subsection of religiosity, among others. Third, religiosity is a sub-division of spirituality. Fourth, spirituality and religiosity are two entirely separate concepts.
} 
Often the spiritual path first starts with a back-ache or need for exercise rather than with a search for meaning - typical examples are taijiquan and yoga. Thus contemporary spirituality encompasses also pragmatic concerns and does not frown on this-worldly problems, such as health issues or stress relief. Body is seen as a gateway to the depths of inner life, and therefore it is also understood as a resource, or a way for attaining greater wellbeing. These spiritual-physical exercises are based on the principle that the human body allows privileged access to one's spirit and emotions. ${ }^{2}$ Contemporary spirituality thus begins with physical embodiment.

At present, there are two major tendencies in the field of physical exercises. One is the current trend of body management and maximum efficiency that leans on the scientific approach to a body and borrows rhetoric from science in marketing: examples are body building and fitness classes like Bodypump ${ }^{\mathrm{TM}}$ or Zumba ${ }^{\circledR}$. The other is the trend of subjectivity and the associated search for individual experience and also spirituality, which emphasizes a personal approach to well-being: yoga and taijiquan, for example. These spiritual-physical exercises face pressure to transmute, as consumer culture appropriates spiritual conceptions of the body and body practices, and transforms these conceptions into new understandings of spiritualities. As part of the acculturation process to become an urban market commodity, Elizabeth De Michelis notes that exercises such as yoga have experienced a wave of endeavors for scientific validation. ${ }^{3}$

This chapter draws attention to physical exercises that approach spirituality through the body, asking what happens as these spiritual-physical exercises gradually give ground in the process of becoming part of the western consumer market, including issues of mind-body

And finally, spirituality and religiosity are overlapping concepts and they share some but not all characteristics.

${ }^{2}$ McGuire, Toward a Sociology of Spirituality: Individual Religion in Social/Historical Context, 215232; Sointu and Woodhead, Spirituality, Gender, and Expressive Selfhood, 259-276.

${ }^{3}$ De Michelis, A Preliminary Survey of Modern Yoga Studies, 1-19. 
dualism and its scientific descendants. Does contemporary cultural fascination with neurobiology and health (sciences) influence the marketplace appropriation of spiritual conceptions of the body? I argue that our society's interest in neurobiology and health defines the way spiritual or therapeutic exercises are reconfigured, conceptualized, and practiced. Furthermore, this chapter discusses how the major trends in the physical exercise market come to merge in spiritual-physical exercises like yoga and Asian martial arts. Following this, spirituality in these exercises may become suppressed, expressed, or interpreted in new and unexpected ways. Contemporary sociology of religion is starting to understand the need to explore this phenomenon.

\section{Modernization of spiritual-physical exercises and their attraction in the cosmopolitan}

\section{marketplace}

As yoga and many Asian martial arts gain global popularity, they are now practiced in countries that do not share their original cultural heritage. These practices have turned into an integral part of urban cultures worldwide, as De Michelis notes on modern yoga. ${ }^{4}$ This trend raises new questions regarding the authenticity and evolvement of the exercises, and how the practitioners of other cultural backgrounds become familiar with religious traditions or negotiate the spiritual dimensions of the art into their belief systems. As a practitioner of Chinese martial arts like taijiquan eventually has to face Chinese religions if she or he wants to fully understand the art, so too will a yogi inevitably meet Hinduism and will a budoka (the practitioner of the group of Japanese martial arts called budō) meet Buddhism, Confucianism, and Shinto. ${ }^{5}$ These activities are deliberately called 'physical exercises' in this chapter, in

\footnotetext{
${ }^{4}$ De Michelis, A Preliminary Survey of Modern Yoga Studies, 1-19.

${ }^{5}$ Many other physical exercises are often viewed as religious and spiritual as well, for example samba and salsa share common ground with some African-derived religious traditions of Latin America, and several studies have established a link between belly dance and spirituality (see Kraus 2009). There are also other leisure activities, such as African and Cuban drumming, that relate to religions, but for the purposes of this chapter the area of interest is confined to the above-mentioned physical exercises.
} 
order to emphasize their place in the cosmopolitan market where they are labeled primarily as physical activities, instead of spiritual, as they could be called in the cultures of their origin. ${ }^{6}$

Although in yoga the physical exercise is also viewed as a way that leads to deeper spiritual being and ultimately to enlightenment, according to the teachings of Hinduism, in the cosmopolitan consumer culture religion is often downplayed and yoga is introduced as a fitness or relaxation (therapeutic) technique. Yoga generally refers to traditional intellectual and physical disciplines originating in India. Although yoga has its roots dating back to at least 1500 years to Patañjali, whom some yogis consider to be its semi-mythical founder, the history of modern yoga is a little over 100 years old. Modern yoga, as De Michelis defines it, refers to "those disciplines and schools which are, to a greater or lesser extent, rooted in South Asian cultural contexts, and which more specifically draw inspiration from certain philosophies, teachings and practices of Hinduism."7

Many scholars date the yoga renaissance and the beginning of modern yoga in the West starting with Swami Vivekananda's (1863-1902) visit to the United States in 1893. Perhaps the two most influential yoga masters of our time are Pattabhi Jois (1915-2009) and B.K.S. Iyengar (1918- ) who both founded their own hatha yoga schools, which now enjoy global popularity: Ashtanga Yoga by Jois and Iyengar Yoga by Iyengar. These two yoga schools have developed into worldwide organizations with branches in dozens of countries in all continents; Iyengar Yoga has schools in 61 countries and Ashtanga Yoga in $26 .^{8}$

\footnotetext{
${ }^{6}$ Although football (both European and American), for example, has been compared to religion and religious experience, this chapter does not take sport as a religion but looks instead into the religions interlinked with physical exercises (regarding sport's relation to religion, see e.g. Magdalinski and Chandler 2002).

${ }^{7}$ De Michelis, A Preliminary Survey of Modern Yoga Studies, 2.

${ }^{8}$ Burger, What Price Salvation? The Exchange of Salvation Goods between India and the West, 83 , 81-95; Van der Veer, Global Breathing - Religious Utopias in India and China, 315-328; Lea, Liberation of Limitation? Understanding Iyengar Yoga as a Practice of the Self, 71-92; De Michelis, A Preliminary Survey of Modern Yoga Studies, 1-19; The Official Website of B.K.S. Iyengar Yoga; Ashtanga Yoga.
} 
Just as all yoga is rooted in Indian philosophy and mystical technology dating back at least to the middle of the first millennium CE, the practice of asanas (the physical postures central to hatha yoga) has a shared history with the philosophical development of yoga. Philosophy in the Indian context always has soteriological goals, although yoga practice does not require worshipping Indian deities. In fact, the soteriological philosophy and the ideas regarding ultimate reality are interpreted with great variety among the many paths of yoga. The Iyengar Yoga teachers in Britain are told not to instruct others which, if any, god to believe in and to avoid making metaphysical comments. Also, although for Ashtanga Yoga the ultimate goal is to realize 'the true nature of selfhood,' the late-modern cosmopolitan context of modern yoga downplays or overlooks the transcendental dimension. ${ }^{9}$

Modernization shows also in Asian martial arts such as budō, whose religious or philosophical background comes from Buddhism, Shinto, and Confucianism. ${ }^{10}$ Budō as a generic term can be used synonymously with all Japanese martial arts, or it may refer to the modern Japanese martial arts developed since the $19^{\text {th }}$ century. In the latter meaning, which is employed in this chapter, these budō are: jūdō, kendō, kyudō, aikidō and karate-dō, of which especially judo and karate - as they are usually transcribed in the cosmopolitan marketenjoy a strong international following. In budō the physical exercise is viewed both as a fighting technique and a way to spiritual growth and ultimately to enlightenment. All these above-mentioned Asian physical exercises have gone through a metamorphosis in the late $19^{\text {th }}$ and $20^{\text {th }}$ centuries. Often this transformation has been about the modernization of the art to meet the social, spiritual, and philosophical ideals of the modern society. ${ }^{11}$

\footnotetext{
${ }^{9}$ Hasselle-Newcombe, Spirituality and 'Mystical Religion' in Contemporary Society: A Case Study of British Practitioners of the Iyengar Method of Yoga, 305-321; Smith, Body, Mind and Spirit? Towards an Analysis of the Practice of Yoga, 27-28.

${ }^{10}$ Young, Bowing to Your Enemies: Courtesy, Budō, and Japan, 188-215.

${ }^{11}$ Tan, Constructing Martial Tradition: Rethinking a Popular History of Karate-dou, 169-192; Villamón et al., Reflexive Modernization and the Disembedding of Jūdo from 1946 to the 2000 Sydney Olympics, 139-156.
} 
Judo is perhaps the best example of the modernization process in Japanese budo, for during judo's history it has undergone conceivably the most severe transformation of all these exercises. It originates in jujutsu, which developed for defense purposes over a period of at least one millennium. The first wave of modernization and of westernization was introduced by the Japanese: Jigorō Kanō (1860-1938), founding judo at the end of $19^{\text {th }}$ century, transmuted the traditional fighting technique of the warrior into judo, which in English means 'the Way of the pliancy', thus emphasizing the $d \bar{o}$ (Way) over jutsu (technique). He also copied modern organizational structure and ideas of efficacy from the West.

Ideologically, judo is a child of the Meiji Restoration in Japan (1868). Meiji Restoration's purpose was to unite western progress with traditional eastern values; with regard to martial arts as judo, its goal was to fuse traditional and modern perspectives in the art. 'Modern' meant, for example, the organization of judo into clubs and federations, while 'traditional' referred to the cultivation of spirituality, deepened sense of self-awareness, and the consciousness that is the Japanese spiritual base of $d \bar{o}$, which shows in its name. Later, the second wave of westernization and of modernization was executed in order to appeal to the spectator sports of western audiences. Since Kanō, judo has gone through great changes, as it is now an Olympic sport with its own federations, competitions, and sponsorships. Kanō was wary about the idea, contemplating that the spirit of judo could die if it became an Olympic discipline. ${ }^{12}$ Consequently, as Kevin Carr puts it regarding the modern judokas, "Sports science is a far more important 'religion' than Zen for this new brand of athlete."13 Thus judo lost its 'Way' when it was transformed into a sport, because in order to conform to

\footnotetext{
${ }^{12}$ Carr, Making Way: War, Philosophy and Sport in Japanese Judo, 167-188; Villamón et al., Reflexive Modernization and the Disembedding of Jüdo from 1946 to the 2000 Sydney Olympics, 139156; Young, Bowing to Your Enemies: Courtesy, Budo, and Japan, 188-215.

Chinese taijiquan tried to follow the footsteps of judo and Korean taekwondo to become an Olympic sport for the Peking 2008 Olympic Games, but the petition was rejected (Ryan 2009, 539-540). Also Bikram Choudhury, the founder of Bikram Yoga with schools in 39 countries, has applied for yoga's admission into the Olympic Games (Howe 2010; Bikram Yoga).

${ }^{13}$ Carr, Making Way: War, Philosophy and Sport in Japanese Judo, 182.
} 
the western taste for spectator sports, it was disembedded from its philosophical and spiritual background. $^{14}$

The Chinese martial art taijiquan—also known as internal boxing—was also influenced by a similar modernization process as Japanese budo in the early $20^{\text {th }}$ century, experiencing the same fascination for western trends in physical exercise. It has already been shown that when discussing the modernization processes of Asian martial arts, one has to remember that the 'West' has not always been the culprit in mutating the arts. The political development of China set serious challenges to traditional taijiquan practice in the country during the $20^{\text {th }}$ century. Mao Zedong wanted to transmute it to an exhibition sport --- the government created a 'modernized' and simplified form of it --- and during the Cultural Revolution the martial artists were persecuted, sending many to flee offshore to places like Taiwan and Hong Kong. Thus in the case of taijiquan, especially, the global market has actually helped to preserve the traditional forms of the art. ${ }^{15}$

\section{The subjective turn in spiritualities and physical exercises}

Several expressions of Asian martial arts and yoga have gained popularity in the urban world over the past few decades, "quietly entering the fabric of everyday Western life". ${ }^{16}$ Although these exercises, as imported commodities, are more predominant in North America and Europe (arguably as parallels to secularization and to the turn to the subjective, discussed in the following pages), one finds yoga, budō, and other Asian martial arts in schools in all continents, including Africa and Latin America.

\footnotetext{
${ }^{14}$ Villamón et al., Reflexive Modernization and the Disembedding of Jūdō from 1946 to the 2000 Sydney Olympics, 139-156.

${ }^{15}$ Ryan, Globalization and the 'Internal Alchemy' in Chinese Martial Arts: The Transmission of Taijiquan to Britain, 525-543; Van der Veer, Global Breathing - Religious Utopias in India and China, 315-328.

${ }^{16}$ Brown and Leledaki, Eastern Movement Forms as Body-Self Transforming Cultural Practices in the West: Towards Sociological Perspective, 123.
} 
There are two major trends in religion and society in the 'West' that help explain the rising popularity of these exercises: One is multiculturalism and the fragmentation of religion: as ideas, cultures, and religions diffuse globally, and the monopoly of Christianity disappears, there is space for more diverse religiosity and spirituality. And the other is secularization and its aftermath, post-secularization.

While secularization was long held to be inevitable in modern society, the rise and diversity of new religious and spiritual phenomena — such as New Age, alternative spiritualities, religious consumerism, and well-being practices - have proved this argument questionable (as has the influence of religion on politics and other spheres of society in the US). ${ }^{17}$ The phenomena of new religiosities and spiritualities may be referred to as reflections of post-secularization. Secularization gave rise to a more tolerant culture, thus enabling new religions and new religious practices. Among these were religions that had a different approach to the body than that taught by the Church. ${ }^{18}$ Since then the Christian body-soul dualism has been challenged by alternative ways of recognizing human beings and their bodies. In physical exercises originating in Asian culture, especially, there are different takes on embodiment.

While spiritual practices are always embodied, in yoga, budō, and the other Asian martial arts the physicality of human beings is a basis for the exercises and their spiritual dimension. These exercises have gained popularity in the wake of the turn toward the subjective. Experienced since 1960s, this is a turn away from life that is lived obeying external or 'objective' roles, duties, and obligations that are given to us by culture and

\footnotetext{
${ }^{17}$ Secularization theories often name dimensions of modernity — such as urbanization, individualization, rationalization, and societalization - as responsible for secularization (Woodhead 2008). On secularization, see also Taylor, A Secular Age; Bruce, Religion in the modern world: from cathedrals to cults.

${ }^{18}$ The focus of religious embodiment, however, Meredith McGuire states, is by no means a novel turn in the history of Christian religiosity. Rather, the disconnection of embodiment and religiosity is a relatively new phenomenon in the West. The Reformation's privileging of belief over practice in definitions of religion and thereby of bodies was almost entirely pushed aside in the conceptualization of religion. (McGuire 2008)
} 
society. Instead, one turns into oneself, to 'subjective life' in which the significance of things do not rise from external matters (for example, how something is valued in the community, workplace or church with which one is connected). Rather, significance rises from the unique experiences of self, when life is lived in deep connection with one's own personal experiences. In religion this means that an individual does not look for answers in authority, institution or dogma, but turns attention to the inside; into one's own emotions, experiences and longings. 'Spirituality' may also include the everyday spiritual lives of ordinary people. ${ }^{19}$ Accordingly, religious practices may evolve to something different than institutionally established conventions; dancing, gardening, jogging, or painting may represent one's spirituality, as well as exercises originating from other, 'exotic' cultural backgrounds. The subjective turn shows not only in spirituality but also in physical exercises. When earlier the variety of physical exercises one could choose from was rather limited, now the repertoire of leisure time activities and exercises is more wide-ranging than ever. Individuals can choose their exercise according to their physical, mental, social, and sometimes spiritual needs of the time. Since popular physical exercises such as yoga, judo and taijiquan are now practiced around the world, they are taught and perceived in new and sometimes unconventional ways in relation to their religious and philosophical backgrounds. The subjective turn, with its experience-oriented approach to leisure time and spirituality, unavoidably affects the appeal of these physical exercises in urban cultures worldwide. In spiritual practices involving the body, Sointu and Woodhead argue, the body is a medium to access one's authenticity, or the inner 'core', reflecting one's true feelings and thoughts one's spirit. In case of judo, taking into account post-secularization and the subjective turn, it

\footnotetext{
${ }^{19}$ Heelas and Woodhead, Spiritual revolution: why religion is giving way to spirituality; Heelas, Spiritualities of life: new age Romanticism and consumptive capitalism; McGuire, Why Bodies Matter: A Sociological Reflection on Spirituality and Materiality, 1-18.
} 
is perhaps not so surprising that it is the western judokas who are now calling for getting the Japanese spiritual base ' $d \bar{o}$ ' back to judo. ${ }^{20}$

\section{The mind-body dualism and scientific approaches to body}

Although modern-day spirituality commonly starts with bodily experience, science and consumerism have permeated contemporary culture so thoroughly that it is not surprising that in one's concern for health, and health-related spirituality, the rhetoric of science is often both appealing and persuasive.

The scientific project of yoga, together with its 'medicalization' began in 1920's India, when attempts were made to bring together modern science and spiritual aspects of yoga. Vivekananda, who is considered a key figure in the introduction of many Hindu philosophies in the West, had already marketed yoga as a scientific tradition to westerners, and the emphasis on mind-body unity in hatha yoga (which in the cosmopolitan market is usually associated with the physical tradition of postural yoga) in particular, offered a popular alternative choice to Americans. Vivekananda's yoga did not specify any religion to adhere to; instead it claimed to be both eastern spirituality and rational science. ${ }^{21}$ Swami Kuvalayananda (1883-1966) was the first to carry out laboratory research on yoga's health effects, believing that the classical yogic literature revealed the truth, or "pure yoga manifest." Continuing on Vivekananda's path, his goal was to prove that this truth was based on natural laws of science; therefore objective science was to be employed as "the handmaiden of spirituality and orthodox philosophy.",22

\footnotetext{
${ }^{20}$ Sointu and Woodhead, Spirituality, Gender, and Expressive Selfhood, 259-276; Villamón et al., Reflexive Modernization and the Disembedding of Jüdo from 1946 to the 2000 Sydney Olympics, 139156.

${ }^{21}$ Alter, Yoga and Physical Education: Swami Kuvalayananda's Nationalist Project, 20-36; De Michelis, A Preliminary Survey of Modern Yoga Studies, 1-19; Van der Veer, Global BreathingReligious Utopias in India and China, 315-328.

${ }^{22}$ Alter, Yoga in Modern India. The Body between Science and Philosophy, 83, 34-87.
} 
One hundred years after Vivekananda, B.K.S. Iyengar, the founder of popular Iyengar Yoga, declared that modern life makes us lose our connection to our bodies, suggesting that we may regain it by "cellular enlightenment", in which we "relax the cells of the brain, and activate the cells of the vital organs and of the structural and skeletal body. Then intelligence and consciousness may spread to each and every cell." ${ }^{23}$ The concept of "cellular enlightenment' is ideologically an offshoot of Vivekananda's and Kuvalayananda's 'science of yoga,' trying to make yoga attractive to modern consumer culture by combining concepts of eastern spirituality and western science. Indeed, part of yoga's attraction is that it dispels the mind-body dualism. This approach appeals to the cosmopolitan exercise market, for it allows practicing non-defined 'eastern' spirituality without making any commitment to Hinduism, while the pretext of being 'scientific' or 'good for your health' disperses any misgivings regarding its ties to religion. Since yoga entered the US health market, Peter van der Veer claims, yoga-promoted Indian spirituality has become a lifestyle element and a market commodity. Today, there are nearly 16 million practitioners of yoga in the United States alone, and 4 million in Germany. ${ }^{24}$

Modern science, David Brown and Aspasia Leledaki argue, has the power to disembed yoga from its philosophical origins, because it can transform the understanding and practice of yoga into a primarily therapeutic form of exercise, thus erasing its ontological ground. ${ }^{25}$ Scientists have become interested on yoga and its health effects. Yet, there are countless research reports of yoga having positive effect on people's health. ${ }^{26}$ Although there

\footnotetext{
${ }^{23}$ In Lea, Liberation of Limitation? Understanding Iyengar Yoga as a Practice of the Self, 84.

${ }^{24}$ Van der Veer, Global Breathing - Religious Utopias in India and China, 315-328; Hayes and Chase, Prescribing Yoga, 31-47; Strauss, Positioning yoga: balancing acts across cultures.

${ }^{25}$ Brown and Leledaki, Eastern Movement Forms as Body-Self Transforming Cultural Practices in the West: Towards Sociological Perspective, 123-154.

${ }^{26}$ See, for example, Brown and Gerbarg on yoga breathing and longevity (Brown and Gerbarg, Yoga Breathing, Meditation, and Longevity, 54-62); Descilo et al. on yoga and posttraumatic stress disorder (Descilo et al., Effects of a yoga breath intervention alone and in combination with an exposure therapy for post-traumatic stress disorder and
} 
are numerous studies on yoga that prove its efficacy, Joseph Alter points out, very little is known about how it works. In research conducted on asthma, for example, the diagnosis of the medical condition caused by respiratory function and allergic pathology is based on western science, but the cure is based on the yogic concept of prāna (the vital life force) and its manipulation. ${ }^{27}$

\section{Concentration}

While it was declared in The Lancet a bit more than a decade ago that doing scientific research on yoga that draws from its secret technology of mind sounded "wacky," today there are numerous studies in which scientists are interested in yoga's philosophical and religious aspects as well. For example, American neuroscientist Richard W. Maxwell discusses the neurobiology of chakras, the centers of concentrated metaphysical energy in the yogic system. Searching for their exact location and origin, he suggests that chakras could match with a locus of gap junctions in certain spots of human body, which arise during embryological development. ${ }^{28}$ Maxwell's study fits into the growing trend of combining the study of religion with neuroscience, in order to find a middle ground between these disciplines without the (apparent) reductionist attempt to explain religion away.

Sometimes neuroscientists like Maxwell lean toward the study of religion, but increasingly as well the scholars of religion try to bridge the gap to neuroscience. For example, Stephen Kaplan compares neuroscience with Advaita Vedānta and asparśa yoga in his attempt to explain the phenomenal boundaries between subject and object, while Ellen Goldberg notes that both cognitive science and yoga make forceful claims concerning the relationship between the body and the mind, especially on three points: they both reject mind-

depression in survivors of the 2004 South-East Asia tsunami, 289-300); Tuzun et al. on yoga and postmenopausal osteoporosis (Tuzun et al., Yoga might be an alternative training for the quality of life and balance in postmenopausal osteoporosis, 69-72).

${ }^{27}$ Alter, Yoga in Modern India. The Body between Science and Philosophy, 152.

${ }^{28}$ Morris, Meditating on yogic science, 1038; Maxwell, Neurobiology of Chakras and Prayer: The Physiological Foundation of Yoga Chakra Expression, 807-824. 
body dualism, they both hold strong views on the nature of consciousness, and they both discuss the role of the nervous and circulatory systems in religious experience. ${ }^{29}$ Many theories of cognitive science are challenging the Cartesian body-mind dichotomy; this new scientific paradigm presupposes interdependence, and utilizes such ideas as embodiment or the ontological rejection of dualism. Both of these ideas are in the very core of hatha yoga traditions, Goldberg notes, as practices like asanas (yoga postures), mantras (repetition of sacred sound), and pranayama (breathing meditation) are meant to lead towards "direct experience of one's own essential nondual nature."30

As the market for eastern spirituality opened, it was not only yoga that flourished, but a variety of Chinese spiritual exercises as well, such as taijiquan. Qigong, which is commonly paired with taijiquan, also gained a transnational market. Chinese qigong includes several forms of exercise that, according to van der Veer, aim to "develop skills (gong) to use the vital energy (qi) present in the body to connect it to the natural world of which the body is a part." 31 Although early communist China did not look favorably upon religious practices, qigong prospered because it was made part of a state-sanctioned medical science, thereby being removed from the realm of superstition into the domain of scientific clinics, as traditional techniques were transformed to meet the scientific standards of China. During the Cultural Revolution both qigong and taijiquan suffered, but as qigong was rediscovered in 1980s and became popular again, it made its way to the global market. There it was sometimes introduced as purely a form of 'health orientation,' sometimes as 'spiritual healing. ${ }^{32}$

\footnotetext{
${ }^{29}$ Kaplan, Grasping at Ontological Straws: Overcoming Reductionism in the Advaita VedāntaNeuroscience Dialogue, 238-274; Goldberg, Cognitive Science and Hathayoga, 613-629.

${ }^{30}$ Goldberg, Cognitive Science and Hathayoga, 620-621.

${ }^{31}$ Van der Veer, Global Breathing - Religious Utopias in India and China, 316.

${ }^{32}$ Van der Veer, Global Breathing - Religious Utopias in India and China, 315-328; Valussi,

Women's Qigong in America, 187-201.
} 
Several studies have been conducted on taijiquan and qigong that verify their health effects. ${ }^{33}$ Neurobiology has also turned its investigating eye on these Chinese spiritual exercises, as the review by Tsang and Fung on neurobiological mechanisms of qigong exemplifies - they looked for neurobiological explanation for qigong's demonstrated antidepressive effects. Alexandra Ryan predicts that due to the current shifts towards improved and provable efficiency in health and medicine, future scientific research will pay more attention to taijiquan. ${ }^{34}$

In karate, as in other budō, mind and body are treated as inseparable. Karate (or karate-dō) is usually translated as 'the Way of the empty hand,' and it is one of the most popular and widely practiced Japanese martial arts in the world. The word empty has two meanings in karate: the self-defense and combat techniques that do not require any weapons, and the 'emptiness' of Zen Buddhism. Karate is often said to have been modernized and thus transformed into a neo-tradition by Gishin Funakoshi (1870-1957), who altered the meaning of karate from 'Chinese hand' to 'empty hand' and added the suffix $d \bar{o}$, 'Way,' thus emphasizing the Zen spirituality of karate. ${ }^{35}$ Karate is both a system of codified fighting skills and as a Zen practice a way to enlightenment. Funakoshi stated that kara (empty) in karate means the "emptiness, void, that lies at the heart of all creation." ${ }^{36}$ Thus it is a physical exercise that actively creates space for non-dualism and tries to avoid the Cartesian mind-

\footnotetext{
${ }^{33}$ See, for example, Rhayun et al. on taijiquan and osteoarthritis (Rhayun et al., $A$ Randomized Study of the Effects of T'ai Chi on Muscle Strength, Bone Mineral Density, and Fear of Falling in Women with Osteoarthritis, 227-233; Wu and Ren on taijiquan and leg muscle activity (Wu and Ren, Speed effect of selected Tai Chi Chuan movement on leg muscle activity in young and old practitioners, 415-421; Yan et al. on qigong and breast cancer (Yan et al., External Qi of Yan Xin Qigong Induces Apoptosis and Inhibits Migration and Invasion of Estrogen-Independent Breast Cancer Cells Through Suppression of Akt/NF- $\kappa B$ Signaling, 263-270).

${ }^{34}$ Tsang and Fung, A Review on Neurobiological and Psychological Mechanisms Underlying the Anti-depressive Effect of Qigong Exercise, 857-863; Ryan, Globalization and the 'Internal Alchemy' in Chinese Martial Arts: The Transmission of Taijiquan to Britain, 541.

${ }^{35}$ Bar-On Cohen, Kime and the Moving Body: Somatic Codes in Japanese Martial Arts, 73-93; Tan, Constructing Martial Tradition: Rethinking a Popular History of Karate-dou, 169-192; Young, Bowing to Your Enemies: Courtesy, Budō, and Japan, 188-215.

${ }^{36}$ 1984; in Young, Bowing to Your Enemies: Courtesy, Budō, and Japan, 188-215.
} 
body dichotomy. ${ }^{37}$ This no-mind, or abandonment of self, dissolves mind-body dualism, as there is no mind to mind the dualism. Elsewhere Funakoshi explains that "just as it is the clear mirror that reflects without distortion, or the quiet valley that echoes a sound, so must one who would study karate-do purge himself of selfish and evil thoughts, for only with a clear mind and conscience can he understand that which he receives." 38

The idea of emptiness in karate washes away both mind-body dichotomy and the division of 'body-mind-spirit' for in that state all categories are gone. This search for emptiness and dissolution of mind-body division appeals to cosmopolitan practitioners around the world. Yet the scientific quest of proving eastern physical exercises healthy or "good for the body and mind," which is so often important for the practitioners, in order to legitimize their art in front of their own eyes and others', ends up fortifying the division because often with validation through western science also comes the scientific paradigm that is bolstered by Cartesian dualism between mind and body. Western science carries a powerful legitimating force that may be used to validate a practitioner's self-cultivation and selfimprovement projects. ${ }^{39}$

Thus the fascination between science and these spiritual-physical exercises goes both ways. On the one hand, physicians and scientists such as neurobiologists are enthralled with both ontological questions regarding humanity and the potential physiological/health benefits of the exercises. On the other hand, practitioners, advocates, and some scholars doing research on these spiritual-physical exercises aim to prove the healthiness of the exercise, validating it in scientific terms, or looking for confirmation regarding mystic techniques from new disciplines like neurobiology.

\footnotetext{
${ }^{37}$ Bar-On Cohen, Kime and the Moving Body: Somatic Codes in Japanese Martial Arts, 73-93.

${ }^{38}$ 1973, 4; in Tan, Constructing Martial Tradition: Rethinking a Popular History of Karate-dou, 170.

${ }^{39}$ Brown and Leledaki, Eastern Movement Forms as Body-Self Transforming Cultural Practices in the West: Towards Sociological Perspective, 123-154.
} 


\section{Spiritual-physical marketplace}

Recent research has helped clarify conceptions of spirituality in North America and Europe. For example, approximately 10-20 percent claim to be "spiritual not religious" and around 20-40 percent believe in "some sort of spirit or life force" or in a "god that is something within each person." ${ }^{40}$ This raises the question of whether the contemporary cultural emphasis on body and mind leaves more space for 'mind-body-spirit' practices than for those of 'mind-body-religiosity'; this question needs to be addressed in future research.

The spiritual marketplace has long recognized and thus catered to the demand of embodiment in modern spirituality. Consumerism, the idea that consumption equates with personal happiness, describes the tendency of people to identify strongly with products or services they consume. In relation to spirituality this means that the consumer culture of wellbeing exercises, holistic approaches to physical exercise and spiritual growth, and 'trademark' exercises, such as the internationally well-branded yoga schools like Iyengar Yoga, Ashtanga Yoga and Bikram Yoga, are now gaining ground in the spiritual-physical marketplace. Individualistic practitioners look for inner subjective experiences, as well as spiritual ones, in the physical exercises under discussion. Consumer culture creates a marketplace to 'pick and choose' those aspects of the practices and experiences that suit the individual at that particular time.

The marketplace of spiritual-physical practices reflects consumerism and the subjective turn in urban cultures worldwide. When these exercises are transformed to appeal to cosmopolitan taste, some spiritual or physical aspects remain, while some get omitted or altered. Exercises such as yoga are sometimes taught and advertised without any reference to

\footnotetext{
${ }^{40}$ Sointu and Woodhead, Spirituality, Gender, and Expressive Selfhood, 259-276. The data drawing from RAMP (Pan-European study of religious and moral pluralism) and other surveys indicate, however, that using 'spiritual' as a concept in surveys and questionnaires is challenging for it may mean very different things to different people: for some it equals religiosity, for others it is dissimilar to it, and yet for others the two concepts cannot be set apart and distinguished that easily (Barker 2008).
} 
their cultural and religious context, in order to fit in the urban late-modern world, in which spiritual exercises that were originally deeply spiritual are often taken as a 'gym sport' or fitness technique. Yet cosmopolitan consumers have also found yoga so appealing because it offers "practical benefits in association with an ancient spiritual tradition," as Newcombe puts it. ${ }^{41}$ This discrepancy between 'fitness technique' and 'spiritual tradition' originates in two major trends in the market field of physical exercises: the trend of body management, toning, and efficiency, ${ }^{42}$ and the subjective turn with its search for inner experience, spirituality, and knowledge. Although these two perspectives may at first seem incompatible, they both arise from the context of consumer culture that celebrates certain kinds of individualism.

There are several spiritual-physical exercises that combine approaches of 'fitness technique' and 'spiritual tradition,' in addition to the above-discussed yoga; taijiquan is a good example. The commonly made division between martial art taijiquan and health taijiquan is in fact mostly superficial, Ryan notes, for taijiquan in general emphasizes physical efficiency, spirituality and holistic orientation. ${ }^{43}$ Taijiquan, like many other Asian martial arts, appeals to cosmopolitan practitioners because it combines, or rather fuses, both major trends in the global fitness market. Furthermore, its advocates attempt to legitimize its philosophy through western scientific validation. Teachers use the scientific evidence in taijiquan-associated qigong, for example, as Brown and Leledaki state, in order to appeal to a potential international cosmopolitan clientele for whom western science is an authoritative

\footnotetext{
${ }^{41}$ Newcombe, Stretching for Health and Well-Being: Yoga and Women in Britain, 1960-1980, 40.

${ }^{42}$ The recent growth of literature on fitness and self-improvement suggests, Hoverd and Sibley (2007) argue, that American religion may have shifted from civil religion suggested by Robert N. Bellah (1967) to the religion of body and self-improvement - exercise has taken the form of a religion, as this-worldly salvation has become into a focus.

${ }^{43}$ Ryan, Globalization and the 'Internal Alchemy' in Chinese Martial Arts: The Transmission of Taijiquan to Britain, 536.
} 
legitimating force. ${ }^{44}$ Thus the scientific approach to body and the fascination with neurobiological understandings of body allow two tendencies to be brought together in the current exercise market. Through the scientific validation adopted by consumer culture the individual may legitimize the subjective and spiritual "but useful and efficient" practice.

The Japanese martial art judo also combines both approaches. Judo is based on the "principle of maximum efficiency in the use of physical and spiritual force," according to its founder Kanō. ${ }^{45}$ This tenet expresses the (seed for the) same combination of ideas that is now rocking the cosmopolitan exercise market - Kanō's remark shows that the ideas of maximum efficiency and spirituality encountered already in Japan, although it took a hundred more years to transform this into neurobiological fascination.

The modernization of spiritual-physical exercises like Japanese budō, in order to appeal to urban late-modern taste, is seeing some signs of attempting to counter-balance the scales, as the earlier example of western judokas longing for the re-spiritualization of judo shows. The post-secularization of the 'West' demands the embodied spirituality the exotic Asian exercises seem to offer. Yet the question remains whether the demand to put the ' $d \bar{o}$ ' back in judo is really an attempt to restore judo to its 'original' state, or if the objective is to make it fit the needs of the cosmopolitan individual who is longing for something spiritual in the aftermath of post-secularization and in the turn toward the subjective, but in her or his own terms.

The consumerist approach to spiritual-physical exercises may clash with their philosophical ground. In all the discussed exercises, the relationship between master and student is light years away from the one of seller and client. Where the master demands loyalty and maintains that the disciple will do the exercises and acquire knowledge when the

\footnotetext{
${ }^{44}$ Brown and Leledaki, Eastern Movement Forms as Body-Self Transforming Cultural Practices in the West: Towards Sociological Perspective, 123-154.

${ }^{45}$ Villamón et al., Reflexive Modernization and the Disembedding of Jüdō from 1946 to the 2000 Sydney Olympics, 139-156.
} 
master sees fit, in a consumer culture the client-practitioner demands information and experiences that fit one's needs at the time. There is a discrepancy in the spiritual-physical marketplace; consumerism, loyalty, and obedience do not go hand in hand. Spiritual-physical exercises, such as taijiquan, face new challenges as they gain ground in new cultural territories as a result of international expansion.

Like yoga and budō, taijiquan has undergone substantial transformations during the last century. It also has been touched by 'modernization', Ryan states, such as pedagogic innovations and the search for more efficient techniques and practices. ${ }^{46}$ The demand for efficacy in pedagogy and in technique is the current trend of the exercise market, which shows in a countless number of 'ten-step-programs,' videos, and guidebooks that promise mastery of an art by following the provided instructions. Therefore, the irony is not lost when an urban cosmopolitan individual seeks an alternative for the lifestyle of consumer culture and fitness techniques, Brown and Leledaki note, but ends up demanding individual and convenient experiences that cause the transformation of physical exercises in the very same direction from which the individual wishes to be liberated. ${ }^{47}$

\section{Conclusion}

This chapter has introduced some perspectives on the multifaceted fabric of spiritualphysical exercises. Individuals choosing to practice these activities are often interested in new or alternative worldviews and belief systems, and some may become involved with the spiritual tradition connected to the exercise. There are also a (small) number of people who start to do, for example, yoga, Hasselle-Newcombe reminds us, because they are already

\footnotetext{
${ }^{46}$ Ryan, Globalization and the 'Internal Alchemy' in Chinese Martial Arts: The Transmission of Taijiquan to Britain, 540.

${ }^{47}$ Brown and Leledaki, Eastern Movement Forms as Body-Self Transforming Cultural Practices in the West: Towards Sociological Perspective, 123-154.
} 
involved with Hinduism. ${ }^{48}$ In most cases, however, the process goes the other way around. Students get involved in new exotic leisure activities and only later become interested in the underlying spiritual traditions. Enthusiasm and the length of time spent with the exercise are important factors, because one is more likely to learn about the profound philosophical matters the longer one spends with the other practitioners. Often in the beginner's class there is hardly any reference to the philosophical and spiritual principles that go hand in hand with the practice, or, if there is, it is represented in general philosophical terms without any reference to the actual spiritual dimensions of the exercise. The teachers do not want to alienate the beginners with the spiritual aspects before there is proper time to discuss things thoroughly. These aspects are considered to be a matter of private deliberation among urban late-modern individuals and thus not proper topics for the introductory classes, where the beginners only learn the first steps of the art. Yet eventually the time will come when these practitioners will have to negotiate, one way or the other, the spiritual principles regarding their belief systems.

Although the modernization and westernization of spiritual-physical exercises started more than a hundred years ago, the late modern urban world, suffused with consumerism and subjectivity, witnessed expansion of embodied spiritual practices in the cosmopolitan marketplace. While part of the attraction of these practices is the alternative take on body and spirituality, paradoxically, eastern practices often endeavor to legitimize the art in the eyes of cosmopolitan consumer culture by employing western scientific rhetoric. The fascination between science and the spiritual-physical exercises is mutual, however; both scientists and advocates of the exercises are keen on finding proof of their health effects, with the advocates also trying to validate their art through a scientific aura. Thus they end up watering down the

\footnotetext{
${ }^{48}$ Hasselle-Newcombe, Spirituality and 'Mystical Religion' in Contemporary Society: A Case Study of British Practitioners of the Iyengar Method of Yoga, 305-321.
} 
different understanding of humanity, body and spirituality, and emphasizing the Cartesian dualism of mind and body.

In modern yoga and budō the physical exercise is viewed as a way leading to deeper spiritual being and ultimately to enlightenment, but in cosmopolitan consumer culture this is often downplayed and these exercises are introduced as fitness techniques. Modern yoga, especially, has developed into teaching techniques and organized educational systems with certified teachers. Iyengar Yoga, Ashtanga Yoga and Bikram Yoga, which are among the most popular yoga schools in the world, are modern organizations with branches in dozens of countries, in all continents. Thus yoga and Asian martial arts like Japanese budō and Chinese taijiquan, in order to fit in the contemporary cosmopolitan world where profoundly spiritual practices are commonly viewed as fitness techniques, are sometimes taught and advertised without any indication as to the religious or cultural background. Urban late-modern individuals find the spiritual traditions of the 'East' appealing but they want to access them conveniently, through the existing mental and organizational framework of the cosmopolitan world. 


\section{References}

Alter, Joseph S. 2007. Yoga and Physical Education: Swami Kuvalayananda’s Nationalist Project. Asian Medicine, Vol. 3: 20-36.

Alter, Joseph S. 2004. Yoga in Modern India. The Body between Science and Philosophy. USA: Princeton University Press.

Bar-On Cohen, Einat. 2006. Kime and the Moving Body: Somatic Codes in Japanese Martial Arts. Body \& Society, Vol. 12(4): 73-93.

Barker, Eileen. 2008. The Church Without God and the God Within: Religiosity and/or Spirituality?, Eileen Barker (ed.) The Centrality of Religion is Social Life. USA: Ashgate. 187-202.

Brown, Richard and Patricia Gerbarg. 2009. Yoga Breathing, Meditation, and Longevity. Longevity, Regeneration, and Optimal Health: Ann. New York Academy of Sciences, 1172:54-62.

Brown, David, and Aspasia Leledaki. 2010. Eastern Movement Forms as Body-Self Transforming Cultural Practices in the West: Towards Sociological Perspective. Cultural Sociology, Vol. 4(1):123-154.

Bruce, Steve. 1996. Religion in the modern world: from cathedrals to cults. New York: Oxford University Press 
Burger, Maya. 2006. What Price Salvation? The Exchange of Salvation Goods between India and the West. Social Compass, Vol. 53(1): 81-95.

Carr, Kevin Gray. 1993. Making Way: War, Philosophy and Sport in Japanese Judo. Journal of Sport History, Vol. 20(2):167-188.

De Michelis, Elizabeth. 2007. A Preliminary Survey of Modern Yoga Studies. Asian Medicine, Vol. 3: 1-19. Brill.

Descilo, T and A Vedamurtachar, PL Gerbarg, D Nagaraja, BN Gangadhar, B Damodaran, B Adelson, LH Braslow, S Marcus, RP Brown. 2010. Effects of a yoga breath intervention alone and in combination with an exposure therapy for post-traumatic stress disorder and depression in survivors of the 2004 South-East Asia tsunami. ACTA PSYCHIATRICA SCANDINAVICA 121(4): 289-300.

Goldberg, Ellen. 2005. Cognitive Science and Hathayoga. Zygon, Vol. 40(3): 613-629.

Hasselle-Newcombe, Suzanne. 2005. Spirituality and 'Mystical Religion' in Contemporary Society: A Case Study of British Practitioners of the Iyengar Method of Yoga. Journal of Contemporary Religion, Vol. 20(3):305-321.

Hayes, Meg and Sam Chase. 2010. Prescribing Yoga. PRIMARY CARE, Vol. 37(1):31-47. 
Heelas, Paul. 2008. Spiritualities of life: new age Romanticism and consumptive capitalism. Malden, MA: Blackwell.

Heelas, Paul and Linda Woodhead. 2005. Spiritual revolution: why religion is giving way to spirituality. Malden, MA: Blackwell.

Hoverd, James William, and Chris G. Sibley. 2007. 'Immoral Bodies: The Implicit Association Between Moral Discourse and the Body'. Journal of Scientific Study of Religion, Vol. 46(3):391-403.

Howe, D. K. 2010. Could Yoga Become an Olympic Sport? American Fitness, Vol. 28(4):4445.

Kaplan, Stephen. 2009. Grasping at Ontological Straws: Overcoming Reductionism in the Advaita Vedānta—Neuroscience Dialogue. Journal of the American Academy of Religion, Vol. 77(2):238-274.

Kraus, Rachel. 2009. The Many Faces of Spirituality: A Conceptual Framework Considering Belly Dance. Implicit Religion, Vol. 12(1): 51-72.

Lea, Jennifer. 2009. Liberation of Limitation? Understanding Iyengar Yoga as a Practice of the Self. Body \& Society, Vol. 15(3):71-92.

Magdalinski, Tara and Timothy J.L. Chandler (eds.). 2002. With God on their Side. Sport in the service of religion. London: Routldege. 
Maxwell, Richard W. 2009. Neurobiology of Chakras and Prayer: The Physiological Foundation of Yoga Chakra Expression. Zygon, Vol. 44(4):807-824.

McGuire, Meredith. 2003. 'Why Bodies Matter: A Sociological Reflection on Spirituality and Materiality'. Spiritus: A Journal of Christian Spirituality, Vol. 3(1):1-18.

McGuire, Meredith. 2008. 'Toward a Sociology of Spirituality: Individual Religion in Social/Historical Context', in Eileen Barker (ed.) The Centrality of Religion is Social Life. USA: Ashgate. 215-232.

Morris, Kelly. 1998. Meditating on yogic science. THE LANCET, Vol. 351: 1038.

Newcombe, Suzanne. 2007. Stretching for Health and Well-Being: Yoga and Women in Britain, 1960-1980. Asian Medicine, Vol. 3:37-63.

Rhayun Song, and Beverly L. Roberts, Eun-Ok Lee, Paul Lam, Sang-Cheol Bae. 2010. A Randomized Study of the Effects of $T^{\prime} a i$ Chi on Muscle Strength, Bone Mineral Density, and Fear of Falling in Women with Osteoarthritis. The Journal of Alternative and Complementary Medicine, 16(3): 227-233.

Ryan, Alexandra. 2009. Globalization and the 'Internal Alchemy' in Chinese Martial Arts: The Transmission of Taijiquan to Britain. East Asia Science, Technology and Society: an International Journal 2:525-543. 
Smith, Benjamin R. 2007. Body, Mind and Spirit? Towards an Analysis of the Practice of Yoga. Body \& Society, Vol. 13(2):25-46.

Sointu, Eeva and Linda Woodhead. 2008. 'Spirituality, Gender, and Expressive Selfhood', Journal for the Scientific Study of Religion, Vol. 47(2): 259-276.

Strauss, Sarah. 2005. Positioning yoga: balancing acts across cultures. Oxford: Berg.

Tan, Kevin S.Y. 2004. Constructing Martial Tradition: Rethinking a Popular History of Karate-dou. Journal of Sport \& Social Issues, Vol. 28(2):169-192.

Taylor, Charles. 2007. A Secular Age. Cambridge: Harvard University Press.

Tsang, Hector, and Kelvin Fung. 2008. A Review on Neurobiological and Psychological Mechanisms Underlying the Anti-depressive Effect of Qigong Exercise. Journal of Health Psychology, Vol. 13(7):857-863.

Tuzun, S and I Aktas, U Akarirmak, S Sipahi, F Tuzun. 2010. Yoga might be an alternative training for the quality of life and balance in postmenopausal osteoporosis. EUROPEAN JOURNAL OF PHYSICAL AND REHABILITATION MEDICINE, Vol. 46(1):69-72.

Valussi, Elena. 2010. Women's Qigong in America. Journal of Daoist Studies, Vol. 3:187201. 
Van der Veer, Peter. 2007. Global Breathing - Religious Utopias in India and China. Anthropological Theory, Vol. 7(3): 315-328.

Villamón, Miguel, and David Brown, Julián Espartero, and Carlos Gutiérrez. 2004. Reflexive Modernization and the Disembedding of Jūdō from 1946 to the 2000 Sydney Olympics. International review for the Sociology of Sport, Vol. 39(2):139-156.

Woodhead, Linda. 2008. 'Gendering Secularization Theory', Social Compass, Vol. 55(2):187-193.

Wu, Ge and Xiaolin Ren. 2009. Speed effect of selected Tai Chi Chuan movement on leg muscle activity in young and old practitioners. Clinical Biomechanics Vol. 24(5):415421.

Yan, Xin, and Hua Shen, Hongjian Jiang, Dan Hu, Chengsheng Zhang, Jun Wang, Xinqi Wu. 2010. External Qi of Yan Xin Qigong Induces Apoptosis and Inhibits Migration and Invasion of Estrogen-Independent Breast Cancer Cells Through Suppression of Akt/NF-кB Signaling. Cellular Physiology \& Biochemistry, Vol. 25(2/3):263-270.

Young, Damon A. 2009. Bowing to Your Enemies: Courtesy, Budō, and Japan. Philosophy East \& West, Vol. 59(2):188-215.

\section{Internet sources}

Ashtanga Yoga. http://www.ashtanga.com/html/classes.html. (Accessed May 15, 2010.) 
The Official Website of B.K.S. Iyengar Yoga.

http://www.bksiyengar.com/modules/Teacher/teacher.asp. (Accessed May 15, 2010.)

Bikram Yoga. http://www.bikramyoga.com/studioListing.php. (Accessed October 6, 2010.) 